\title{
RETHINKING UNDERGRADUATE CURRICULA: A DELPHI STUDY OF HUMAN RESOURCE MANAGEMENT AND INDUSTRIAL \& ORGANISATIONAL PSYCHOLOGY
}

\author{
A VENTER \\ N BARKHUIZEN \\ Department of Human Resource Management \\ University of Johannesburg
}

\begin{abstract}
The aim of this qualitative study is to bring clarity to the confusion about the interconnectedness, similarities and differences between the fields of Human Resource Management (HRM) and Industrial \& Organisational Psychology (I\&OP), for the purposes of curriculum development. The Delphi technique was used to gather data from 13 participants (five international and eight national). Analysis was done interpretively using Atlas.ti. Results indicate that HRM and I\&OP are distinct but interrelated fields of study and can therefore be presented in separate but interrelated undergraduate curricula.
\end{abstract}

\section{OPSOMMING}

Die doel van die kwalitatiewestudie is om duidelikheid te verkry oor die verwarring rakende die interverwantskap, ooreenkomste en verskille tussen die velde van Menslike Hulpbronbestuur (MHB) en Bedryfs- en Organisasie Sielkunde vir die doeleindes van kurrikulumontwikkeling. Die Delphi tegniek is gebruik om data van 13 deelnemers (vyf internasionaal en agt nasionaal) te versamel. Ontleding is op 'n interpreterende wyse gedoen deur gebruik te maak van Atlas.ti. Die resultate toon dat MHB en Bedryfs- en Organisasie Sielkunde onderskeibare, maar verbandhoudende studievelde is en daarom aangebied kan word in afsonderlike, maar interverwante voorgraadse kurrikula.

It was once remarked that professors are to education as goldfish are to water: they swim in the water but never think to study it (Gmelch, Wilke \& Lovrich, 1986). Indeed, we as academics and researchers willingly study other groups, yet we seldom take time to look at our own profession. However, with universities now preoccupied with a shift from an industrial to a knowledge economy, with globalisation and the emergence of new information and technologies, it is necessary to take stock of what we teach our students.

According to Lee (2002), undergraduate and graduate degrees in human resources are becoming increasingly important to Human Resource (HR) careers, particularly as HR professionals heed the call to step up to the boardroom table and become strategic partners of companies. But many academic programs in social science suffer from confusion over what should be taught. In South Africa, for instance, the ontological and epistemological dimensions of Industrial Psychology have created so much confusion that some universities delegated this field towards Human Resource Management (Watkins, 2001). Consequently, industrial psychologists often fill human resource management positions in practice (Schreuder, 2004). Furthermore, as academics tend to struggle to find ways of bridging their separate and distinct disciplines, practitioner divisions are being questioned and eroded as they are increasingly regarded as dysfunctional in achieving the flexibility and speedy responses demanded of the modern corporation (Knights \& Wilmott, 1997). As a result Human Resource Management (HRM) lacks credibility, not only because of the function of the profession but also because of the people who perform the function (Beer, 1997, p. 54).

Against this background it is clear that what we teach has important repercussions for the development of human resource-related professions. There is therefore undoubtedly a need to reconceptualise higher education curricula. However, if one is to achieve this, it is necessary to take a step back and gain a fuller understanding of the confusion by examining (1) the history of the HR function; (2) how the past impacted theory development; and (3) the current practice of HR.

Requests for copies should be addressed to: A Venter, aven@uj.ac.za

\section{Historical background}

It is exceedingly difficult to write a definitive history of a discipline, to divide it into units of time or even apply a date to the founding of it. The fields of Industrial Psychology and HRM are no exemption to this difficulty. For example, depending on the author consulted, Industrial Psychology may have started in 1901 (Blum \& Naylor, 1968), 1904 (McCarthy, 2002) or 1923 (Watkins, 2001). Human Resource Management may have been founded in the 1700s (Swanepoel, Erasmus, Van Wyk, \& Schenk, 2003), 1910 (Ferris, Hall, Royle \& Martocchio, 2004) or 1920 (Ferris, Hochwarter, Buckley, Harrel-Cook, \& Frink, 1999). A reflection on historical time sequence therefore does not illuminate which field emerged first and can consequently be labelled as the 'parent' field. History does, however, provide an understanding of a discipline and its sub-fields, its evolution, functions, practice, and may even enable us to make predictions about the future.

The study of HRM, as a field of scientific inquiry, and as a potential profession, began around the time of World War I. At that time scientific management (Taylor, 1911), the welfare work movement and Industrial Psychology (Munsterberg, 1913) are reported to have merged to form HRM (Ferris, Hall et al., 2004). Industrial Psychology, on the other hand, is reported to have emerged as an applied field of psychology with the goal of increasing employee efficiency by improving employee wellbeing. Hugo Munsterberg's famous book Psychology and Industrial Efficiency (1913) is regarded by many as the authoritative source in the field of applying psychological knowledge to the management of work and human resources. Although the preceding information seems clear about the origins of Industrial Psychology and HRM, it is worth highlighting that Taylor was also a founding father of Industrial Psychology (Schreuder, 2004). Clearly, then, the historical developments of Industrial Psychology and HRM are interrelated and intertwined.

\section{South African Context}

The evolution of the HRM field in South Africa took place over three major periods: personnel management, industrial relations and strategic human resource management. Initially, the emphasis was on the personnel management aspects of HRM, which were introduced to South Africa in the 1940 s by an industrial 
psychologist, Isobel White, also nicknamed the 'mother of personnel management' (Swanepoel et al., 2003). The research done by Mrs White led to the establishment of the first postgraduate qualification for the South African personnel field, namely a 'Diploma in Personnel Welfare and Management', and also the first personnel department in a South African organisation, which was formed in the South African mining industry. However, if one is to look at the typical duties of South African personnel managers in the 1950s (as described by Swanepoel et al., 2003, p. 47), they overlap with those described for industrial psychologists internationally (see Blum \& Naylor, 1968, p. 9).

The growth in importance of unions from the 1930s to the 1950s resulted in a marked shift from the personnel management aspects of HRM to Industrial Relations (IR). IR has been characterised as an interdisciplinary field of study involving professionals from such areas as law, business economics, economics, sociology, psychology and anthropology. Many of these professionals, at least loosely, associated themselves with the human relations movement (Bendix, 1989; Kaufman, 1993). IR had its 'golden age' from the 1950 's up to the early eighties. During the same time, Industrial Psychology also became popular at South African universities (Schreuder, 2004). In practice almost half of the graduate staff performing personnel work had psychology as a major subject and almost a fifth of them industrial psychology as a major subject (Swanepoel et al., 2003). Furthermore, the origin and epistemological dimension of industrial psychology is also found in work done by psychologists, sociologists and anthropologists (Watkins, 2001). Clearly then, industrial psychology has very much the same roots as the IR aspects of HRM.

In light of the above it is remarkable that IR (now also referred to as employment relations) is considered in some circles to be a sub-field of industrial psychology (Schreuder, 2004). Scholars, however, have also debated the question whether IR subsumes HRM, or whether IR is a component of HRM (Ferris, Hall et al., 2004).

To take this point further, the HRM field, once responsible for record-keeping and maintenance, has evolved into a strategic partner, sharing comparable boardroom status with disciplines such as accounting, marketing, and engineering (Dulebohn, Ferris, \& Stodd, 1995). More recently industrial psychologists, in adopting a strategic perspective, enabled themselves to relate in more meaningful ways with their clients by demonstrating their ability to support corporate goals. At the same time they proved themselves capable of making a business case for what they do (Bornman, Klimoski, \& Ilgin, 2002). The evolution to strategic partnering has therefore not caused the fields to diverge from each other, but has instead intertwined them even more.

In summary, it is evident from historical literature that the field of industrial psychology had a significant part to play in the emergence of the field of HRM, but is not the sole contributor. With its emphasis on the well-being of the employee, it can be argued that industrial psychology probably contributed to the development of the so-called 'soft version of HRM', which sees human beings as a unique resource that needs to be led, motivated and communicated with (Leopold, 2002). The 'hard version of

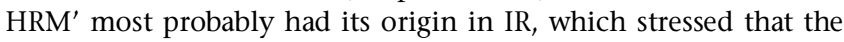
human resource is on par with other resources such as capital or land. However, in spite of its contributions to HRM, it is evident that industrial psychology had very much the same origins as HRM, and this in turn might have contributed to further confusions in theory development and, eventually, practice.

Next, we investigate whether theory development or practice can explain the differences between HRM and industrial psychology.

\section{Theory}

Theory development is fundamental to any field because it is the basis on which ideas are tested and new knowledge and insights are gained. Moreover, it has been argued that the primary goal of theory is to answer the questions of how, when and why (Bacharach, 1989). In particular, Ulrich (1997) suggested that HR needs theories which explain why HR delivers what it does. Critics, however, have argued that both industrial psychology and HRM lack a general, integrated, acceptable and grand theory (England, 1976, p. 15; Mahoney \& Deckop, 1986; Wright \& McMahan, 1992).

According to Pietersen (1986), industrial psychology is in a chaotic theoretical-conceptual 'state'. This may be a function of the fact that industrial psychology is still profoundly influenced by clinical, counselling and educational psychologists with their psychoanalytical, behaviourist and humanist ideas (Watkins, 2001). Moreover, cognitivist, behaviourist and humanist theories, combined with the archetypes of psychoanalysis (id, ego and superego) also had a significant part to play in the field's theoretical foundation. However, these multiple and diverse influences created so much confusion that some universities preferred to establish the field as Human Resource Management, which is taken to be constituted by industrial psychology with an array of psychology-related topics (Watkins, 2001).

Ironically, despite their own 'theoretical confusions', most of the early reviews of literature on Human Resource Management were published by notable industrial psychologists (Ferris, Hochwarter, et al., 1999). Consequently, these HRM reviews tended to emphasise applied individual-level issues, such as employee testing, training and motivation. Irrespective of the industrial psychological influences, theoretical development in the field of HRM has been piecemeal and has emerged from several other disciplines, including psychology, sociology, economics and management/organisation studies (Ferris, Hall, et al., 2004). It has been argued that HRM lacks a grand theory because the myriad disciplinary perspectives that inform HRM research lack grand theories themselves.

The lack of sound theory also presents some serious consequences for the research, and practice, of HRM. With regard to research it has been argued that empirical tests lack sufficient theoretical underpinnings (Wallace, 1983), and that new 'disciplinary' knowledge cannot be gained if theory is not developed further (Dulebohn et al., 1995). In terms of HRM practice, Ulrich (1997) cites the need for practice to be guided by HR theory. He reminds HRM professionals that theory helps explain the manner in which outcomes emerge:

"To make HR practices more than isolated acts, managers and HR professionals must master the theory behind HR work; they need to be able to explain conceptually how and why HR practices lead to their outcomes ... regardless of the preferred theory, managers and HR professionals should abstract from it a higher level of reasoning for their day-to-day work and thus better explain [how] their work accomplishes its goals". (Ulrich, 1997, p. 238)

Turning again to industrial psychology, the precise role of the industrial psychologist in industry remains unclear, despite the field's sound theoretical foundations (Watkins, 2001). Nevertheless, these theoretical developments led to the emergence of two clusters of competencies for industrial psychologists: personnel psychology and organisational psychology. From these clusters emerged a new term for the field called Industrial and Organisational Psychology (I\&OP). According to Cascio (1987), personnel psychology represents the overlap between psychology and personnel management (a subset of HRM). In this context, personnel psychology is thus part of both personnel management (HRM) and industrial and organisational psychology. Another line of research suggests that personnel psychology is often referred to as 'personnel management', 'industrial psychology', 'human resource management' and so on (Schreuder, 2004). There are, however, distinct differences between personnel psychology and personnel/human resource management. According to Cascio (1998, p. 3, cited in Schreuder, 2004), "personnel psychology is an applied discipline that focuses on individual differences in behaviour 
and job performance, while personnel/human resource management is the attraction, selection, retention, development and utilisation of human resources in order to achieve both individual and organisational objectives."

Bearing this in mind, a fundamental question that emerges is: if personnel psychology and personnel management/HRM are so different, why are the names regularly used interchangeably? Can the confusion perhaps stem from semantic issues? Few areas of research, teaching or writing, have evoked as much semantic debate as that which abounds in the literature concerning the field of human resource management (Swanepoel et al., 2003). The current debate about the 'correct' name for the HRM field even extends to whether the term should be 'human resources management' (plural) or 'human resource management' (singular) (Mathis \& Jackson, 1991). Ehrlich (1997), for instance, suggested that the variety of names over years may also give an indication of where the field is heading. Indeed, whereas most experts would agree that HRM is the concept that replaced concepts such as personnel administration or personnel management, there is considerable debate in the Western world regarding what exactly HRM entails. Some authors refer to it as 'old wine in new bottles' - a more fashionable name for personnel management (Leopold, 2002). Some authors still refer to the function as personnel/human resource management (combined) (see Mathis \& Jackson, 1991; Cascio, 1998).

\section{Practice}

Another debate that stems from confusion over the fields of HRM and I\&OP concerns the practice of HRM in the workplace. Some authors argue that it is a line function (Schreuder, 2004; Leopold, 2002). Others view it as a function of all managers (Grobler, Wärnich, Carrell, Elbert \& Hatfield, 2003; Swanepoel et al. 2003). Some South African studies recommended that industrial psychologists should perform HRM functions (Pienaar $\&$ Roodt, 2001). The typical duties for personnel/HRM managers described by Cascio (1998) overlap to a great extent with a profile compiled by Tustin (1993) for industrial psychologists in South Africa. Several other studies in South Africa have been conducted in order to identify certain key competencies for industrial psychologists and human resource managers (Tustin \& Flowers, 1993; Van der Westhuizen, Van Vuuren, \& Visser, 2003; Veldsman, 2001, for a review). All of these studies indicate that there is great overlap in the workplace practices of the fields of HRM and I\&OP.

\section{Aim of the study}

The aim of this study is to bring clarity to the confusion about the interconnectedness, similarities and differences between the fields of Human Resource Management (HRM) and Industrial \& Organisational Psychology (I\&OP), for the purposes of integrating the findings into a framework within which an undergraduate curriculum at a university can be developed. Therefore, the study will focus on the current state and future directions of HRM and I\&OP.

Various approaches can be adopted in investigating the fields of HRM and I\&OP for curriculum development purposes. Broadbased content analysis of relevant literature can extrapolate existing themes (Naisbitt, 1990; Wheeler, 1988 cited in Czinkota $\&$ Ronkainen, 2005, p. 112). The preceding study of the literature revealed a set of confusing and often contradictory data on the historical, theoretical and practical underpinnings of HRM and I\&OP. A content analysis of literature, therefore, is not sufficient.

The use of interviews and surveys is an alternative investigative approach (Czinkota \& Ronkainen, 2005). Interviews require considerable time commitment and geographical proximity and they do not afford the opportunity for interaction amongst participants. Surveys often result in self-selected participation and also do not facilitate interaction amongst participants. Both interviews and surveys furthermore require substantial time and financial resources. A requirement of this study is to elicit existing and new thoughts on the two fields of study, namely HRM and I\&OP, through expert participation, participant interaction as well as consensus-building and debate. These requirements could be satisfied through the use of the Delphi technique.

\section{The Delphi technique}

The Delphi technique is an effective and reliable data-collection method that is particularly useful when there is uncertainty, or little knowledge, about the area being investigated (Crisp, Pelletier, Duffield, Adams, \& Nagy, 1997). Furthermore, the Delphi technique is future-oriented - its name is derived from the Greek oracle at Delphi, from whom the Greeks sought advice about the future (Cohen, Harle, Woll, Despa, \& Munsell, 2004; Bijl, 1996 cited in Costa, 2005). The technique was originally developed for forecasting technological developments, but has since been used in a range of different situations, including curricular evaluation and planning in higher education (Clayton, 1997; Gibson, 1998; Cohen et al., 2004; Howze \& Dalrymple, 2004).

In this study the Delphi technique ensured the building of consensus around opinions (Williams, Boone, \& Kingsley, 2004) regarding HRM and I\&OP. The opinions of the participants were aggregated over three rounds to achieve majority consensus, giving participants the opportunity to provide their opinion as well as to enter into debate with the other participants under conditions of full anonymity (Williams et al., 2004). Research indicates that three iterations are typically sufficient to identify points of consensus and systematic points of difference, and that more iterations can bore panellists, thus reducing the validity of findings (Jones, Sanderson, \& Black, 1992). Anonymity, and the fact that participants never physically came together, ensured that participants and their personality factors were equalised, thereby minimizing participant biasing effects (Hardy et al., 2004; Howze \& Dalrymple, 2004; Czinkota \& Ronkainen, 2005). Since the study required participants to debate and interact with each other, the Delphi technique created the opportunity for participants to state their opinion and also consider the opinion of other participants. This meant that participants could modify their initial impressions in the light of insight gained from the feedback after each round (National Public Health Partnership, 2000; Hardy et al., 2004).

\section{METHOD}

\section{Research questions}

On the basis of the aim of the study and the literature review the following research questions were posed:

- What are the perceived similarities between Human Resource Management and Industrial \& Organisational Psychology?

- What are the perceived differences between Human Resource Management and Industrial \& Organisational Psychology?

- What are the perceived unique contributions of Human Resource Management and Industrial \& Organisational Psychology?

\section{Participants}

The Delphi technique requires that panellists are experts in the field they are being questioned on (Martino, 1983). Therefore it was necessary to identify scholars who could be considered experts. For the success of this study, it thus was critical to secure the participation of the right kinds of experts, who understand the issues and represent a substantial variety of viewpoints. The participants were academic staff members of South African and international higher education institutions. International academics were selected on the basis of their expert knowledge and publication record. National academics were selected on the basis of an internet search of departments or units that present HRM and/or I\&OP at all of the 22 public higher education institutions in the country. 
From the initial pool of nominations, thirty-nine (39) respondents were formally invited to participate. Thirteen (13) agreed to complete the required three rounds of the survey. Table 1 indicates the country and actual number of participants. The thirteen participants included seven academics from five South African higher education institutions, one expert from a private higher education institution, and five academics from five international higher education institutions.

\section{TABLe 1}

NUMBER OF PARTICIPANTS BY COUNTRY

\begin{tabular}{lc}
\hline Country & Participants \\
\hline United Kingdom & 2 \\
USA & 3 \\
South Africa & 8 \\
Total & 13 \\
\hline
\end{tabular}

One academic who declined to participate did however exchange emails with the researchers and provided insight into the study. This was integrated into the final results of the study after the last round of questionnaires. This academic is not included among the thirteen participants. According to Dalkey (1969), cited in Costa (2005), empirical examination of the Delphi technique suggests that a linear increase in accuracy occurs as the panel increases to 11 members. Therefore the participation rate was considered adequate.

\section{Data collection}

Powell (2003, cited in Hardy et al, 2004) indicates that Delphi purists criticise the use of pre-existing information prior to proceeding with the Delphi. This Delphi study started without pre-conceived notions regarding the similarities and differences between the fields of study under investigation. Participants were sent three rounds of questionnaires. The first round consisted of three open-ended questions. The second round consisted of aggregated information in a typology format as well as a network diagramme. The third round consisted of a typology and definitions for clarification. In each of the three rounds the questionnaires were sent out and received back electronically via email. Anonymity was ensured by the fact that email messages were sent out individually rather than in combined multipleaddressee form. Respondents were requested to respond within a working week each time and responses were received electronically via email. Data analysis took up to three weeks for each round. International respondents tended to respond within two days of receiving the questionnaire. Respondents located nationally were slower in their response reaction time.

\section{Data analysis}

The main aim of the Delphi technique is to determine majority consensus. The approach to data analysis, i.e. through ranking scales and consequent statistics or through determining common themes in an interpretive manner, influences the establishment of consensus. This study was analysed utilising an inductive approach. Throughout the three rounds two researchers analysed the data and discussed their differences in interpretation with each other. During the second round of analysis findings were discussed with two additional colleagues who had expert insight into the fields of study but did not form part of the Delphi participant group. This ensured that the analysis was constantly verified and had rigour.

The first round of data was loaded onto the Atlas.ti data analysis program. The first step in this round of analysis was to analyse the data per participant. Themes were elicited from each participant's response, sentence by sentence, and coded. Theme elicitation was facilitated by taking the overall aim of the study into account - namely the interconnectedness, similarities and differences between the fields of HRM and I\&OP. Where participants made reference to interlinks between data, i.e. 'is part of' or 'leads to', the data was electronically linked. An initial network representing these links was created on Atlas.ti. The second step in the analysis was to analyse data across the codes - i.e. across the aggregated responses. Codes were grouped into themes. The themes were converted into headings of a typology, which distinguished between HRM and I\&OP. This meant that information was converted into combined text, predominantly into a typology, and returned to participants for verification, comment and additions.

The second round of data was analysed by comparing each participant's comments and additions made against the items in the typology. Participants furthermore made comments regarding the overall presentation. Some participants also included additional information in their email messages. During analysis all the respondent's comments were transcribed onto a main typology. Differences in opinion were accommodated by noting these, and changing wording accordingly on the typology. Typology headings were added and removed where necessary and the network, which predominantly indicated areas of overlap, was removed from the final round of the questionnaire. Different interpretations of the elements on the typology gave rise to disagreement. The establishment of common interpretations of meaning ensures that disagreement is reduced (McDonnell et al. cited in Hardy et al, 2004). Common interpretations were stated at the beginning of the second questionnaire.

The final round of the questionnaire represented the main points of consensus from the participants. Areas where consensus was not achieved were highlighted in analysis notes. These areas were debated by the two analysts to determine whether they contradicted anything on the typology. Contradictions were included in the final questionnaire. The analysis of the final comments made by participants on the final round, through comparison similar to the second round, showed no contradictions. Therefore the non-consensus items are not included in the results presented in this article.

Buckley (1995, cited in Howze \& Dalrymple, 2004) cautions that the Delphi technique is "based on preference more than prediction". Jones and Hunter (1995, cited in Graham \& Milne, 2003) point out that consensus does not necessarily mean that the correct answer has been found. Suggestions to overcome these limitations indicate that the results of a Delphi study should be related to other more observable quantitative measures in cases where the aim of the study is to describe behaviour. Since this study did not describe behaviour, a second stage of verification of results was executed. The second stage of verification was achieved through an open meeting in an academic department of a higher education institution. All academics present were practising in either/or HRM and I\&OP. The available results were presented to the meeting. Delegates suggested changes which were noted and included in the final results (Graham \& Milne, 2003). The opportunity for individual feedback and discussion after the open meeting was created.

\section{Judging consensus}

The traditional manner in which Delphi studies are analysed after the first round of open ended questions is through the use of ranking scales, which are converted into statistics. In this instance a suitable criterion for judging consensus is $51 \%$ (Loughlin \& Moore, 1979, cited in Hardy et al., 2004). Another criterion would be to set a 'very high priority' for those items that were rated as six or seven on a 7-point Likert scale, by $70 \%$ of participants, or 'high priority', for those items rated as five, six, or seven by $80 \%$ of participants (Salmond, 1994, cited in Hardy et al., 2004). Dajani et al. (1979, cited in Hardy et al., 2004) suggests that setting consensus criteria in this manner is arbitrary and "... may not always represent consensus of opinion". 
Since this study was analysed in an interpretive manner and data were aggregated and presented in a typology format, statistical determinations of consensus were not appropriate. Consensus was determined through data saturation and the elimination of non-consensus items. Elimination was achieved in two ways namely, through the responses of the participants during the questionnaire rounds and through discussion between the two researchers after the final round.

\section{RESULTS}

\section{Participation}

The number of participants per round are indicated in Table 2 . Rounds two and three had fewer than the 11 participants recommended by Dalkey (1969, cited in Costa, 2005). This was as a result of travel and business commitments. Findings from each round, as summarised in the next round's questionnaire, were distributed to all the participants, which means that all the participants had an equal opportunity to participate. All five international participants returned questionnaires in each of the rounds. An open meeting, where findings were shared and discussed amongst HRM and I\&OP academics, augmented the process and served as a method to validate findings. Since the study was exploratory in nature, the results are deemed valid and should elicit further debate and research on the matter.

TABLE 2

\section{NUMBER OF PARTICIPANTS}

\begin{tabular}{lccccc}
\hline Participants & Round 1 & Round 2 & Round 3 & Open meeting & Email debate \\
\hline National & 8 & 4 & 5 & 14 & 1 \\
International & 5 & 5 & 5 & - & - \\
Total & 13 & 9 & 10 & 14 & 1 \\
\hline
\end{tabular}

The instruments used and the results obtained are presented next per round of the Delphi study.

\section{Round 1}

\section{Instrument - survey}

Three open-ended questions were posed in the first questionnaire, namely:

1. What are the perceived similarities between Human Resource Management and Industrial \& Organisational Psychology?

2. List the perceived differences between Human Resource Management and Industrial \& Organisational Psychology under each heading below:

- Human Resource Management

- Industrial \& Organisational Psychology

3. List the perceived unique contributions of Human Resource Management and Industrial \& Organisational Psychology under each heading below:

- Human Resource Management

- Industrial \& Organisational Psychology

Results

Table 3 presents a sample of the codes generated on Atlas.ti. The codes are presented below either I\&OP or HRM, depending on what they were describing. A third column contains codes that indicated an overlap between the two fields. In the columns codes are listed from most grounded (number of quotations linked to them) to least grounded.

\section{Mental models}

Three main mental models underpinned responses in the first round. These mental models are depicted in Table 4 .

TABLE 4

\section{MENTAL MODELS}

\begin{tabular}{lll}
\hline Mental model & & Participants \\
\hline $\begin{array}{l}\text { Mental model 1: } \\
\text { I\&OP superior to } \\
\text { HRM }\end{array}$ & $\frac{\text { I\&OP }}{\text { HRM }}$ & $\begin{array}{l}4 \text { national participants and 1 } \\
\text { international participant }\end{array}$ \\
$\begin{array}{l}\text { Mental model 2: } \\
\text { One and the same }\end{array}$ & I\&OP = HRM & 1 national participant \\
$\begin{array}{l}\text { Mental model 3: } \\
\text { Related but distinct }\end{array}$ & I\&OP $\leftrightarrow$ HRM but $\neq$ & $\begin{array}{l}4 \text { international participants } \\
\text { and 4 national participants }\end{array}$ \\
\hline
\end{tabular}

First-round responses received from some participants who are industrial psychologists leaned toward a representation of I\&OP as superior to HRM (refer to mental model 1 - table 4). Proponents of mental model one indicated that HRM forms part of I\&OP, and does not exist in its own right - as is supported by the following quotation:

"HR management has developed out of the research and studies that have been completed by I/O psychologists over a long period of time..." (Participant 10: lines 13-16)

Mental model one holds that HRM is not 'scientific' in its approach or research, and therefore deemed to maintain the status quo. HRM was described as highly procedural and mechanistic in nature. This supported the notion that HRM is not a science as compared to I\&OP. Only one international participant supported mental model one.

The second mental model was that I\&OP and HRM are the same in so many respects that it is impossible to distinguish between the two. Mental model three indicated that I\&OP is related to HRM, as is HRM to I\&OP, but that they were separate fields of study and therefore can be distinguished from each other. Four international participants supported the third mental model. An equal number of national participants supported both mental models one and three.

TABLE 3

\section{Code groundedness}

\begin{tabular}{|c|c|c|}
\hline I\&OP & HRM & Overlap \\
\hline $\begin{array}{l}\text { - I\&OP apply psychology to workplace issues } \\
\text { - Understand people behaviour in org } \\
\text { - I\&OP = scientific (unique science) } \\
\text { - I\&OP human in workplace focus } \\
\text { - I\&OP person job/person environment fit } \\
\text { - I\&OP focus on individual level issues } \\
\text { - Improvement in behaviour/ performance of } \\
\text { - } \text { people in workplace } \\
\text { - I\&OP knowledge generation vs. development } \\
\text { - I\&OP mecialist function outsourced }\end{array}$ & 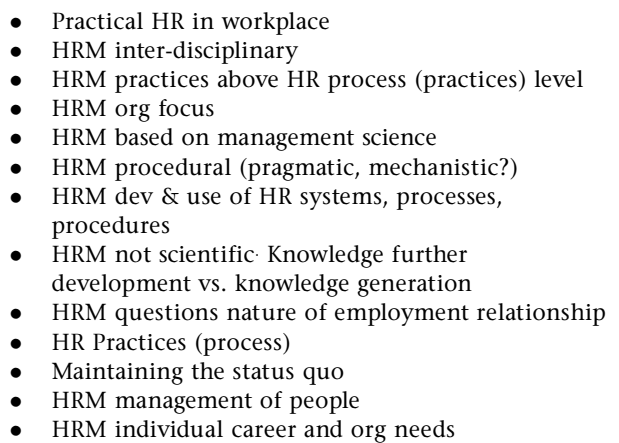 & $\begin{array}{l}\text { - Both human behaviour in workplace } \\
\text { - } \text { HRM subset of I\&OP } \\
\text { - } \text { Individual, group and org levels } \\
\text { - Both in workplace context } \\
\text { - Both functional side of people } \\
\text { - Both support functions to line management } \\
\text { - Both human cognition } \\
\text { - Both managing people in org } \\
\text { - Both HR practices } \\
\text { - Both goal getting best out of employees for org } \\
\quad \text { in RSA }\end{array}$ \\
\hline
\end{tabular}


TABLE 5

\section{A TYPOLOGY OF THE DISTINGUISHING FACTORS OF THE TWO FIELDS OF STUDY}

\begin{tabular}{|c|c|}
\hline Dimensions & I\&OP \\
\hline $\begin{array}{l}\text { Primary focus } \\
\text { groups) }\end{array}$ & Focus on humans (individuals and groups) in the workplace \\
\hline Application of & Psychology to the workplace \\
\hline Level of application & $\begin{array}{l}\text { Bottom-up approach } \\
-\quad \text { Starting at individual level } \rightarrow \\
\text { - } \quad \text { Moving to group level } \rightarrow \\
\text { - } \quad \text { Moving to organisational level }\end{array}$ \\
\hline $\begin{array}{l}\text { Investigate, understand and } \\
\text { explain }\end{array}$ & $\begin{array}{l}\text { People and their behaviour in the workplace context from a } \\
\text { psychological perspective }\end{array}$ \\
\hline $\begin{array}{l}\text { Primary roles in the } \\
\text { organisation }\end{array}$ & $\begin{array}{l}\text { - Specialist } \\
\text { - Industrial \& Organisational Psychologist }\end{array}$ \\
\hline $\begin{array}{l}\text { Management of contract } \\
\text { type }\end{array}$ & $\begin{array}{l}\text { Psychological-social contract (viewing the world from the } \\
\text { employee's side) }\end{array}$ \\
\hline $\begin{array}{l}\text { Client focus (who is the } \\
\text { primary client unit?) }\end{array}$ & $\begin{array}{l}\text { - The individual; or } \\
\text { - The profession }\end{array}$ \\
\hline Academic discipline & $\begin{array}{l}\text { - Disciplinary - based on the discipline of psychology } \\
\text { - Industrial \& Organisational Psychology defines the context } \\
\text { of application of psychology, namely the workplace. } \\
\text { - Relies on various forms of applied psychology to inform } \\
\text { practices and research, e.g. personnel psychology, } \\
\text { organisational psychology, career psychology, consumer } \\
\text { psychology, mathematics and statistics. }\end{array}$ \\
\hline
\end{tabular}

Research

Overall goal
- Primarily occurs within disciplinary boundaries i.e. psychology

- Drive of research is to make new discoveries about human behaviour in the workplace

- Emphasis on generalising findings to generate theory for the academic discipline

- Problems/opportunities not necessarily defined in localised context

- Rules of quality control are well established and unique to the discipline

- Rules conform with discipline's notion of sound scientific practice

- Generation of new knowledge as well as use of existing knowledge to produce new discoveries

Improve organisational functioning throughunderstanding the interaction between humans and their work environment from a psychological perspective

\section{HRM}

Focus on the organisation (which is made up of individuals and

Management principles to human resource decisions in the workplace

Top-down approach

- Starting at strategic organisational level $\rightarrow$

- Moving to organisational unit $\rightarrow$

- Moving to individual employee

How the human side of the enterprise fits into, or influences, organisational strategy from a management perspective

\section{- HR manager}

- Generalist

Employment contract (viewing the world from the organisation's side)

- The management team; or

- The organisation

- Multi-disciplinary - based on Management Studies

- 'Human Resource' defines a functional area of management with its own process and functions i.e. the HR process

- Relies on various disciplines to inform practices and research, e.g. labour law, economics, industrial sociology, industrial anthropology, management studies, industrial and organisational psychology, engineering, computer science, accounting, mathematics and statistics.

- Multi-disciplinary*in nature

- Drive of research is to seek solutions for human resourcerelated problems/opportunities in a specific localised context

- Emphasis on localised application of findings for a specific context instead of generalising findings

- Rules of quality control adaptable according to the disciplinary $\mathrm{mix}^{\star}$

- Generation of new knowledge as well as use of existing knowledge to produce new discoveries

Improve organisational functioning thoughunderstanding the organisational strategy and applying that to the management of human resources

* Level of integration between disciplines as defined by Jantsch (OECD, 1972) in Mc Neill (1999):

Level 1: Multi-disciplinary - there is autonomy in the different disciplines that will not lead to changes in the existing disciplinary or theoretical structures;

Level 2. Inter-disciplinary - there is co-operation between the disciplines to formulate a uniform, discipline-centred terminology or common methodology;

Level 3: Trans-disciplinary (also referred to as cross-disciplinary) - "research based on a common theoretical understanding and accompanied by mutual interpenetration of disciplinary epistemologies" (McNeill, 1999).

Round 2 and 3

Instrument - survey

Questionnaires 2 and 3 were compiled in a table format and participants were requested to comment on and/or verify the statements in the tables. Overall assumptions were stated in the third questionnaire.

Results

Overall assumptions:

Table 5 describes two interrelated fields of academic study. Information in the table is an attempt to distinguish between the two areas and not to separate the areas from each other. The information, furthermore, is based primarily on future aspirations instead of current practice. It must be noted that references to the 'workplace' refer to all types of organisational contexts and that references to 'humans' include individuals as well as groups, which make up the organisation.

\section{Open meeting}

During the open meeting participants emphasised that social psychology led to organisational psychology. Therefore on the I\&OP side of Table 5, the focus on the individual is correct. I\&OP focuses on "the industrious person that works within an organisation" (Raubenheimer, 2005). Therefore the overall nomenclature is Industrial and Organisational Psychology.

\section{DISCUSSION}

Distinct but interrelated areas of study

It is evident from the available literature on the history, growth and development of both HRM and I\&OP that there is a great deal of confusion regarding the interrelatedness, differences and similarities between the areas of study. This confusion complicates the development of undergraduate curricula since the designers and presenters of the curricula themselves do not have a sound framework with which to distinguish between the two areas of study. The confusion is in addition a contributing factor to the entanglement of the roles that an industrial psychologist and a human resource manager perform in the workplace. In South Africa the majority of students graduating as industrial psychologists are employed as human resource managers/practitioners. Whereas this is not necessarily a problem, it does indicate that in their training, South African industrial psychologists are taught human resource management practices, perhaps to a greater extent than their exposure to industrial psychology-based practices. This academic drift results in an overestimation of the 'ownership' that I\&OP has of HRM. The effect on HRM is that as an area of study its undergraduate curriculum tends to be very mechanistic and highly influenced by one predominant discipline - psychology as embodied in industrial psychology. The Delphi results 
indicate that HRM and I\&OP can be conceived of as distinct but interrelated areas of study.

\section{Multi-disciplinarity}

Results from the Delphi study point strongly to the multidisciplinarity of HRM as an area of study. A great deal of focus was placed on the importance of integrating other disciplines into the training of HRM practitioners, as is illustrated by the following quotation:

“...if you are teaching human resource planning then important feeder disciplines are economics and statistics; if you are teaching recruitment and selection an important feeder discipline is industrial psychology (particularly if selection testing is involved); if you are teaching diversity management then an important feeder is industrial anthropology..." (Participant 13: lines 22-27)

In this sense I\&OP becomes one of the feeder disciplines as opposed to the 'parent discipline' of HRM. Implications for curriculum development purposes can be approached in two ways. Firstly an undergraduate curriculum could include subjects such as anthropology, economics, statistics, HRM, as separate subjects. A second way could be to redesign the HRM subject content to reflect the multitude of feeder disciplines. The HRM content should therefore not only include HR process information (augmented by industrial psychology) but rather HR process information augmented by the particular feeder discipline(s) that matches the specific HR process or topic. Greater emphasis on true multi-disciplinarity is therefore achieved.

\section{Focus on the organisation}

The results of the Delphi study show that HRM has a different point of departure from I\&OP. The organisation, its goals and the strategy with which it aims to achieve its goals carry primary importance. In this sense HR management is one of the many functions of general management. HR management therefore interfaces with all of the organisational management functions in order to achieve the goals of the overall organisation. Translated into the undergraduate curriculum, this finding highlights the importance of teaching HRM in tandem with business studies. HRM course content should principally focus on the achievement of organisational goals. These goals include the goals of the people of the organisation but are not necessarily driven by the uniqueness and needs of the individual within the organisation (an industrial psychology focus). The overall goal of HRM therefore is to improve organisational functioning though understanding the organisational strategy and applying that to the management of human resources.

\section{Research}

HRM research, in comparison to I\&OP research, was described as driven by seeking solutions for human resource-related problems/opportunities in a specific, localised context e.g. an organisation. As a result of the multi-disciplinarity of the research, the rules of quality control become adaptable according to the disciplinary mix. Conforming to disciplinebased norms and conventions is therefore not essential. In the area of HRM new knowledge is generated and existing knowledge is developed, in order to produce new discoveries. The elitist notion that HRM merely applies knowledge that has "... been [developed] by I\&O psychologists over a long period of time ..." is refuted. This argument has no substance since all forms of knowledge are interconnected, and a similar argument could be made regarding the knowledge production that preceded $I \& O$ psychology. What may add to the confusion in the original argument is that, in South Africa, as stated before, the majority of industrial psychologists are employed as human resource managers. They therefore view the roles and tasks of an HR manager from an industrial psychology perspective. In practice HRM research by implication is currently conducted from an industrial psychology viewpoint and norms. The Delphi study does, however, bring another perspective on the place and uniqueness of HRM research to the fore. A future direction in HRM research is that the unit of analysis should focus more on the organisation and not so much on the individual.

\section{International differences}

International participants indicated that in organisations the functions of an industrial psychologist are mostly outsourced because of its specialised nature. HRM, on the other hand, was seen as part of the core functioning of organisations and therefore not outsourced. International participants, furthermore, did not present a mental model that I\&OP are superior to HRM. Half of the national participants did, however, hold this view. The mental models that curriculum developers hold are indicative of the content and direction of their curricula and by implication that which students are exposed to.

'Studies' versus 'science'

In the first round of the Delphi study, participants indicated that HRM formed part of 'management science'. When this response was returned to the participants in the second round, a participant indicated that management science is based on 'applied mathematics' as management science is associated with 'operations research'. In this sense a recommendation to curriculum developers is that the term 'science' should be used with caution in the naming of subjects or qualifications. A more inclusive naming is 'studies', e.g. HR studies or management studies, except in the event of referring to management science in its true sense.

In conclusion the purpose of the study namely, to explore the differences, uniqueness and interrelatedness of HRM and I\&OP, has been achieved. From table 5 it is evident that HRM and I\&OP are distinct but interrelated fields of study and can therefore be presented in separate, but interrelated curricula. Although HRM is a multi-disciplinary field, also influenced by I\&OP, it is not subservient to Industrial and Organisational Psychology. For the further development of knowledge, each of the two fields should become more focused. Research in I\&OP should be directed towards the subject discipline of psychology. HRM research, on the other hand, should to be directed at localised contexts with an inter-disciplinary focus and the organisation as the unit of analysis.

The study had various limitations. First the participants of this study were all academic staff members. Secondly the typology, as reflected in table 5 , highlights the fact that participants easily articulated the dimensions of HRM but had greater difficulty in doing so for I\&OP. This resulted in emphasis placed on the uniqueness of HRM in table 5. Future studies could benefit from the inclusion of HRM/I\&OP practitioners as participants in order to broaden the input of opinions. Research should additionally focus on clarifying the uniqueness of I\&OP, to assist in the development of undergraduate curricula, as this is not clearly articulated in the present typology.

\section{REFERENCES}

Bacharach, S. (1989). Organisational theories: Some criteria for evaluation. Academy of Management Review, 14, 496-515.

Beer, M. (1997). The transformation of the Human Resource Management Function: Resolving the tension between a traditional administrative and a new strategic role. Human Resource Management, 36, 49-56.

Bendix, S. (1989). Industrial Relations in South Africa. Cape Town: Juta.

Blum, M.L. \& Naylor, J.C. (1986). Industrial Psychology: Its theoretical and social foundations. New York: Harper.

Bornman, W.C., Klimoski, R.J. \& Ilgen, D.R. (2002). Stability and change in Industrial and Organisational Psychology. Manuscript made available by authors.

Cascio, W.F. (1987). Applied Psychology in personnel management (3rd ed.). Englewood Cliffs, NJ: Prentice-Hall, Inc. 
Cascio, W.F. (1998). Applied Psychology in Human Resource Management. Upper Saddle River, NJ : Prentice Hall.

Clayton, M.J. (1997). Delphi: A technique to harness expert opinion for critical decision-making tasks in education. Educational Psychology, 17, 273-287.

Cohen, M.Z., Harle, M., Woll, A.M., Despa, S. \& Munsell, M.F. (2004). Delphi survey on nursing research priorities. Oncology Nursing Forum, 31, 1011-1018.

Costa, C.A.. (2005). The status and future of sport management: A Delphi study. Journal of Sport Management, 19, 117-143.

Crisp, J., Pelletier, D., Duffield, C., Adams, A. \& Nagy, S. (1997). The Delphi Method? Nursing Research, 46, 116-118.

Czinkota, M.R. \& Ronkainen, I.A. (2005). A forecast of globalization, international business and trade: Report from a Delphi study. Journal of World Business, 40, 111-123.

Dulebohn, J.H., Ferris, G.R. \& Stodd, J.T. (1995). The history and evolution of human resource management. In G.R. Ferris, S.D. Rosen \& D.T. Barnum (Eds.), Handbook of human resource management (pp. 18-41). Oxford, UK: Blackwell.

Ehrlich, C.F. (1997). Human Resource Management: A changing script for a changing world. Human Resource Management, 36, 85-89.

England, G.W. (1976). Conceptual foundations of industrial and organizational psychology. In Dunnette, M.D. (Red). Handbook of industrial and organizational psychology. Chicago: Rand McNally.

Ferris, G.R., Hall, T.H., Royle, M. T. \& Martocchio, J.J. (2004). Theoretical development in the field of human resource management: Issues and challenges for the future. Organisational Analysis, 12, 231-254.

Ferris, G.R., Hochwater, W.A., Buckley, M.R., Harrell-Cook, G. \& Frink, D.D. (1999). Human Resource Management: Some new directions. Journal of Management, 25, 385-415.

Gibson, J.M. (1998). Using the Delphi technique to identify the content and context of nurses' continuing professional development. Journal of Clinical Nursing, 7, 451-459.

Gmelch, W.H., Wilke, P.K. \& Lovrich, N.P. (1986). Dimensions of stress among university faculty: Factor-analytic results from a national study. Research in Higher Education, 24, 266-286.

Graham, L.F. \& Milne, D.L. (2003). Developing basic training programmes: A case study illustration using the Delphi method in clinical psychology. Clinical Psychology and Psychotherapy, 10, 55-63.

Grobler, P.A., Wärnich, S., Carrell, M.R., Elbert, N.F. \& Hatfield, R.D. (2002). Human resource management in South Africa (2nd ed.). London: Thomson Learning.

Hardy, D.J., O’Brien, A.P., Gaskin, C.J., O’Brien, A.J., MorrisonNgatai, E. et al. (2004). Practical application of the Delphi technique in a bicultural mental health nursing study in New Zealand. Journal of Advanced Nursing, 46, 95-109.

Howze, P.C. \& Dalrymple, C. (2004). Consensus without all the meetings: Using the Delphi method to determine course content for library instruction. Reference Services Review, 32, 174-184.

Jones, J., Sanderson, C. \& Black, N. (1992). What will happen to the quality of care with fewer junior doctors? A Delphi study consultant physicians views. Journal of Royal College Physics, 26, 36-40.

Kaufman, B.E. (1993). The origins and evolution of the field of industrial relations in the United States. Ithaca, NY: ILR Press.

Knights, D. \& Willmott, H. (1997). The hype and hope of interdisciplinary management studies. British Journal of Management, 8, 9-22.

Lee, K. (2002). Academic HR programs need to satisfy today's demands. Retrieved June 15, 2005, from the World Wide Web: http://www.benefitnews.com/career/detail.cfm?id=3683
Leopold, J. (2002). Human Resource in Organisations. England: Pearson Education Ltd.

Mahoney, T.A. \& Deckop, J.R. (1986). Evolution of concept and practice in personnel administration/human resource management (PA/HRM). Journal of Management, 12, 223-241.

Martino, J. (1983). Technological forecasting for decision making (2nd ed.). New York: Elsevier.

Mathis, R.L., \& Jackson, J.H. (1991). Personnel/Human Resource Management ( $6^{\text {th }}$ ed.). St. Paul, MN: West Publishing.

McCarthy, P.M. (2002). Dr. Patrick McCarthy's brief outline of the history of I/O Psychology. Retrieved June 1, 2005, from the World Wide Web: http://www.mtsu.edu/ pmccarth/io_ hist.htm

McNeill, D. (1999). On interdisciplinary research: with particular reference to the field of environment and development. Higher Education Quarterly, 53, 312-332.

Munsterberg, H. (1913). Psychology and industrial efficiency. Boston: Houghton Mifflin.

Naisbitt, J. (1990). Megatrends. New York: Morrow.

National Public Health Partnership. (2000). National Delphi study on public health functions in Australia. Report on the findings. Retrieved 20 March 2005 from the World Wide Web: http://www.dhs.vic.gov.au/nphp/

Pienaar, Y. \& Roodt, G. (2001). Die teenswoordige en toekomstige rolle van Bedryfsielkundiges in Suid-Afrika. Journal of Industrial Psychology, 27, 25-33.

Pietersen, H.J. (1986). 'n Oorsig van kritiek rondom Bedryfsielkunde as suiwer en toegepaste wetenskap. Journal of Industrial Psychology, 12, 19-23.

Raubenheimer, I.vW. (2005, February). Personal communication.

Schreuder, A.M.G. (2004). The historical development of industrial psychology. In P.M. Muchinsky, H.J. Kriek \& A.M.G. Schreuder (Eds.), Personnel Psychology (2nd ed.) (pp. 219). Cape Town, Oxford University Press.

Swanepoel, B., Erasmus, B., Van Wyk, M. \& Schenk, H. (2003). South African Human Resource Management: Theory and Practice ( $3^{\text {rd }}$ ed.). Lansdowne, Juta \& Co Ltd

Taylor, F.W. (1911). Shop Management. New York: Harper.

Tustin, C.M. \& Flowers, J. (1993). Industrial psychology and industrial relations: A South African perspective. Journal of Industrial Psychology, 19, 9-13.

Tustin, C.M. (1993). A profile of the industrial psychologist in South Africa. Tydskrif vir Bedryfsielkunde, 19, 1-5.

Ulrich, D. (1997). Human resource champions: The next agenda for adding value and delivering results. Boston: Harvard Business School Press.

Van der Westhuizen, C., Van Vuuren, L.J. \& Visser, D. (2003). Human resource management as a profession in South Africa: Practitioners' perspectives. SA Journal of Human Resource Management, 1, 1-12.

Veldsman, T.H. (2001). A new playing field, game and/or different rules? Into the future with Industrial Psychology as a discipline and profession. Journal of Industrial Psychology, 27, 34-41.

Wallace, M.J., Jr. (1983). Methodology, research practice, and progress in personnel and industrial relations. Academy of Management Review, 8, 6-13.

Watkins, M.L. (2001). Industrial Psychology: An identity crisis and future direction. Journal of Industrial Psychology, 27, 8-13.

Williams, D.L., Boone, R. \& Kingsley, K.V. 2004. Teacher Beliefs about Educational Software: A Delphi study. Journal of Research on Technology in Education. 36 (3), 213-229.

Wright, P.M. \& McMahan, G.C. (1992). Theoretical perspectives for strategic human resource management. Journal of Management, 18, 295-320. 